\section{A simple radial diffusion technique for measuring selectivity of proteinuria}

B M JONES AND A S P HUA Clinical Immunology Unit, Department of Pathology, and Department of Medicine, Queen Mary Hospital, Hong Kong

Glomerular permeability can be defined in terms of the relative clearances of proteins of low and high molecular weight, ${ }^{1}$ proteinuria being selective when small amounts of high molecular weight protein appear in the urine and non-selective when large amounts of high molecular weight protein are excreted. The degree of protein selectivity is related to the type and severity of the renal lesions and to the responsiveness of the disease to treatment with steroids, ${ }^{2-6}$ and thus the determination of protein selectivity has important clinical implications.

An agar gel double diffusion assay has been used to determine relative concentrations of transferrin and $a_{2}$-macroglobulin in urine and serum, ${ }^{5}$ urine/ serum ratios for the two proteins being obtained by visual matching of thickness, intensity, and position of precipitin lines formed when dilutions of the urine and serum under test were diffused towards dilutions of antisera to transferrin and $\alpha_{2}$-macroglobulin. This tedious and subjective method has now been superseded by sensitive rocket immunoelectrophoretic or nephelometric techniques which employ protein standards to determine absolute concentrations of proteins in serum and urine. This communication describes a simple radial diffusion assay for determining protein selectivity which is considerably more precise and less subjective than the agar gel double diffusion assay and yet does not require the sophisticated apparatus or the expensive protein standards required for determination of absolute concentrations of proteins.

The agar gel for the radial immunodiffusion method consisted of $1 \%$ Special Noble Agar in $0.1 \mathrm{M}$ glycine-EDTA buffer, $\mathrm{pH} 7 \cdot 0$, to which was added $0.1 \%$ sodium azide. Rabbit anti-human transferrin and rabbit anti-human $\alpha_{2}$-macroglobulin antisera (Behringwerke) were added to separate aliquots of melted agar to give dilutions of $1 / 60$ and $1 / 100$ respectively. $5 \mu \mathrm{l}$ aliquots of patient's serum diluted $1 / 8,1 / 16$, and $1 / 32$ in $0.1 \mathrm{M}$ glycineEDTA buffer, $\mathrm{pH} 7 \cdot 0$, and of urine concentrated to $60 \mathrm{mg}$ protein/ml by adding Lyphogel (Gelman Instruments $\mathrm{Co}$ ), were added to $2.5 \mathrm{~mm}$ diameter, $2.5 \mathrm{~mm}$ deep wells punched in anti- $\alpha_{2}$-macroglobulin plates; similarly, $5 \mu$ l of serum at $1 / 8,1 / 16$, and $1 / 32$, and of urine concentrate diluted $1 / 32$, were added to wells cut in anti-transferrin plates. Agar plates were incubated at room temperature in moistened chambers for 18 hours, and then precipitin ring diameters were measured using the Hyland precision viewer with graduated eyepiece.

The Protein Selectivity Index $(\mathrm{K})$ is calculated from the formula:

$$
\mathrm{K}=\frac{\log \text { clearance of transferrin }-\log \text { clearance of } \alpha_{2} \text {-macroglobulin }}{\log \mathrm{M} \text { Wt transferrin }-\log \mathrm{MWt} \alpha_{2} \text {-macroglobulin }}
$$

$$
\begin{aligned}
& =\frac{\log \left[\begin{array}{l}
\text { transferrin concentration } \\
\text { in urine } \times \text { urine volume } \\
\text { per minute } \\
\text { transferrin concentration } \\
\text { in serum }
\end{array}\right]-\log \left[\begin{array}{l}
{\left[\begin{array}{l}
\alpha_{2} \text {-macroglobulin concentration } \\
\text { in urine } \times \text { urine volume } \\
\text { per minute }
\end{array}\right.} \\
\begin{array}{l}
a_{2} \text {-macroglobulin concentration } \\
\text { in serum }
\end{array}
\end{array}\right]}{\log 90000-\log 840000} \\
& =\frac{\log \left[\frac{\text { urine }}{\text { serum }} \text { transferrin }\right]-\log \left[\frac{\text { urine }}{\text { serum }} a_{2} \text {-macroglobulin }\right]}{-0.9701}
\end{aligned}
$$

In order to determine urine/serum transferrin and urine/serum $a_{2}$-macroglobulin, a calibration line is drawn on semilog graph paper of precipitin

Received for publication 21 January 1980 ring diameter (arithmetic scale) against the reciprocal of the serum dilution ( $\log$ scale). The point at which the precipitin ring diameter for urine concentrate intersects the graph gives the reciprocal of the serum dilution that contains an amount of transferrin 
(x) or of $\alpha_{2}$-macroglobulin (y) equal to that in the urine concentrate:

$$
\begin{gathered}
\therefore \text { Urine transferrin } \times 1 / 32 \text { (dilution of urine concentrate) } \\
\times \text { concentration factor }=\text { serum transferrin } \times 1 / \mathrm{x} \\
\text { and urine } a_{2} \text {-macroglobulin } \times 1 / 1 \text { (dilution of urine concentrate) } \\
\times \text { concentration factor }=\text { serum } a_{2} \text {-macroglobulin } \times 1 / \mathrm{y} \\
\therefore \mathrm{K}=\frac{\log \left[\frac{1}{\mathrm{x} \times \text { concentration factor }}\right]-\log \left[\frac{1}{\mathrm{y} \times \text { concentration factor }}\right]}{-0.9701}
\end{gathered}
$$

This formula can be simplified by cancelling out the urine concentration factors (therefore the concentration step does not have to be done with great accuracy). For simplicity, the negative sign is dropped, and the working formula becomes:

$$
K=\frac{\log \left[\frac{32}{x}\right]-\log \left[\frac{1}{y}\right]}{0.9701}
$$

Fifty-two patients with proteinuria ranging from 0.3 to $30.0 \mathrm{mg} / \mathrm{ml}$ have to date been assessed using the radial diffusion method, and correlation of $K$ values with type and severity of disease and with response to steroids will be the subject of a further communication (Hua and Jones, in preparation). Taking the value of $\mathrm{K}=1.9\left(\alpha^{1}\right.$-macroglobulin clearance $2 \%$ of transferrin clearance) as the cut-off between selective and non-selective proteinuria, ${ }^{5}$ 20 patients had indices $<1.9$ (non-selective), while in $32 \mathrm{~K}$ was $\geqslant 1.9$ (selective). Urine from 12 of the 32 patients with selective proteinuria contained no demonstrable $\alpha_{2}$-macroglobulin, and in these cases:

$$
\begin{aligned}
K & =\frac{\log \left[\frac{32}{x}\right]-\left[\log \frac{1}{\infty}\right]}{0.9701} \\
& =\frac{\log \left[\frac{32}{x}\right]-[\bar{\infty}]}{0.9701} \\
& =\infty, \text { ie, highly selective }
\end{aligned}
$$

The radial diffusion method is highly sensitive. Urine/serum ratios of transferrin as low as 0.00032 could be measured, while ratios for $a_{2}$-macroglobulin as low as $\mathbf{0 . 0 0 0 0 6}$ were obtained. While lacking the sophistication of modern methods of protein analysis, the method described here is simple, rapid, and inexpensive to perform, and in our hands has yielded information of considerable value in the evaluation of patients with nephritis.

\section{References}

${ }^{1}$ Hardwicke J, Soothill JF. CIBA Foundation Symposium on Renal Biopsy. Wolstenholme and Cameron: Churchill, 1961.

2 Joachim JR, Cameron JS, Schwartz M, Becker EL. Selectivity of protein excretion in patients with the nephrotic syndrome. J Clin Invest 1964;43:2332-46.

${ }^{3}$ Cameron JS, White RHR. Selectivity of proteinuria in children with the nephrotic syndrome. Lancet, $1965 ; 1: 463-5$.

4 Hitzig WH, Anarrichio S, Benninger JL. Clearance spezifischer plasma protein fractionen bei nierenleiden. Klin Wochenschr 1965;43:1154-66.

5 Maclean PR, Robson JS. A simple method for determining selectivity of proteinuria. Lancet 1967;1: $539-42$.

${ }^{6}$ Adeniyi A, Hendrickse RG, Soothill JF. Differential protein clearances and response to treatment in Nigerian nephrotic children. Arch Dis Child 1976; $51: 691-6$.

Requests for reprints to: Dr BM Jones, Department of Pathology, Queen Mary Hospital Compound, Hong Kong. 